\title{
Macrococcus brunensis sp. nov., Macrococcus hajekii sp. nov. and Macrococcus lamae sp. nov., from the skin of llamas
}

Correspondence

Ivo Sedláček

ivo@sci.muni.cz

\author{
Sylva Mannerová, ${ }^{1}$ Roman Pantůček, ${ }^{2}$ Jiří Doškař, ${ }^{2}$ Pavel Švec, ${ }^{1}$ \\ Cindy Snauwaert, ${ }^{3}$ Marc Vancanneyt, ${ }^{3}$ Jean Swings ${ }^{3}$ and Ivo Sedláček ${ }^{1}$ \\ ${ }^{1}$ Czech Collection of Microorganisms, Faculty of Science, Masaryk University, Tvrdého 14, \\ 60200 Brno, Czech Republic \\ ${ }^{2}$ Department of Genetics and Molecular Biology, Faculty of Science, Masaryk University, \\ Kotlářská 2, 61137 Brno, Czech Republic \\ ${ }^{3}$ BCCM/LMG Bacteria Collection, Ghent University, K. L. Ledeganckstraat 35, B-9000 Ghent, \\ Belgium
}

\begin{abstract}
Eight strains of Gram-positive, catalase- and oxidase-positive cocci were isolated from the skin of llamas (Lama glama L.) and characterized using a polyphasic approach. These strains were assigned to the genus Macrococcus on the basis of their phenotypic properties (resistance to bacitracin and sensitivity to furazolidone) and DNA base content (40-42 mol\% G $+\mathrm{C}$ ).

Phylogenetic analysis based on 16S rDNA confirmed that the strains are members of the genus Macrococcus. They differed from all hitherto described macrococcal species in their production of phosphatase and reduction of nitrate (most strains) and the inability to produce acid from glycerol or to grow in $7.5 \% \mathrm{NaCl}$. Ribotyping (EcoRI), macrorestriction analysis (Xbal) and fatty acid methyl ester analysis divided the strains from llamas into three stable clusters. Moreover, ribotyping differentiated the strains analysed not only from previously described macrococcal species but also from oxidase-positive staphylococci. DNA-DNA hybridization confirmed that the three clusters represent separate genomic groups (similarity values $<54 \%$ ). All the results showed that the strains represent three novel species, for which the names Macrococcus hajekii sp. nov. (type strain $\mathrm{CCM} 4809^{\top}=\mathrm{LMG} 21711^{\top}$ ), Macrococcus brunensis sp. nov. (type strain CCM $4811^{\top}=$ LMG $21712^{\top}$ ) and Macrococcus lamae sp. nov. (type strain CCM $4815^{\top}=$ LMG $21713^{\top}$ ) are proposed.
\end{abstract}

Gram-positive, catalase-positive cocci represent a large group of genera inhabiting different environments (water, soil, plants) as well as animals and humans. The skin and body surfaces of animals provide a large area for microbial colonization. Bacteria from these sources appear to be saprophytes, commensals or parasites, but they can also play an important role in various infections (Kloos et al., 1992, 1998; Murray, 1992; Stackebrandt et al., 1995). Staphylococcal and macrococcal strains are common on the skin of animals and may be differentiated from other Grampositive, catalase- and oxidase-positive cocci by the $\mathrm{G}+\mathrm{C}$ content of their DNA, their susceptibility to furazolidone $(100 \mu \mathrm{g})$ (Baker, 1984; Kloos et al., 1998) and resistance to bacitracin (0.04 U) (Falk \& Guering, 1983; Kloos et al.,

Published online ahead of print on 16 May 2003 as DOI 10.1099/ ijs.0.02683-0.

The GenBank/EMBL/DDBJ accession numbers for the 16S rRNA gene sequences of $M$. hajekii CCM 4809 ${ }^{\top}$, M. brunensis CCM $4811^{\top}$ and M. lamae CCM 4815 ${ }^{\top}$ are respectively AY119685-AY119687.
1998). The genus Macrococcus was described by Kloos et al. (1998) with the reclassification of Staphylococcus caseolyticus Schleifer et al. 1982 as Macrococcus caseolyticus and the description of three novel species, Macrococcus carouselicus, Macrococcus equipercicus and Macrococcus bovicus. All these species originate from animal sources (ponies, horses, cows and a food-processing factory) (Kloos et al., 1998). Macrococci are similar to oxidase-positive, novobiocinresistant staphylococci (Staphylococcus sciuri complex) but differ in their somewhat higher $\mathrm{G}+\mathrm{C}$ content, larger cells and the inability to produce acid from D-cellobiose (Kloos et al., 1976, 1997, 1998; Webster et al., 1994). Identification of macrococci at the species level on the basis of phenotypic tests alone is unreliable, and molecular and chemotaxonomic methods must be applied.

In the present study, eight atypical Gram-positive, catalaseand oxidase-positive cocci were isolated from the surface microflora of llamas. Phenotypic tests and selected molecular biological methods were used for their exact 
taxonomic characterization. All the results obtained indicated that these strains represent three hitherto undescribed macrococcal species, for which we propose the names Macrococcus brunensis sp. nov., Macrococcus hajekii sp. nov. and Macrococcus lamae sp. nov.

\section{Bacterial strains}

M. caseolyticus CCM $3540^{\mathrm{T}}$, M. bovicus CCM $4655^{\mathrm{T}}$ and CCM 4656, M. carouselicus CCM 4650 ${ }^{\mathrm{T}}$, CCM 4651 and CCM 4652, M. equipercicus CCM $4653^{\mathrm{T}}$ and CCM 4654, Staphylococcus vitulinus CCM $4511^{\mathrm{T}}$, Staphylococcus lentus CCM $3472^{\mathrm{T}}$, S. sciuri subsp. sciuri CCM $3473^{\mathrm{T}}$, S. sciuri subsp. rodentium CCM $4657^{\mathrm{T}}$ and CCM 4658 and S. sciuri subsp. carnaticus CCM $4835^{\mathrm{T}}$ were used as reference strains. The strains isolated from llamas have been deposited in the Czech Collection of Microorganisms as M. brunensis CCM 4808, CCM 4810, CCM $4811^{\mathrm{T}}\left(=\mathrm{LMG} 21712^{\mathrm{T}}\right)$ and CCM 4813, M. lamae CCM 4812, CCM 4814 and CCM $4815^{\mathrm{T}}\left(=\mathrm{LMG} 21713^{\mathrm{T}}\right)$ and M. hajekii CCM $4809^{\mathrm{T}}(=\mathrm{LMG}$ $\left.21711^{\mathrm{T}}\right)$.

\section{Strain isolation and cultivation}

All the strains were isolated from the skin of llamas in Brno Zoo. Samples were collected using sterile swabs from non-hairy parts of the llama's bodies (nostrils, groin and abdomen, around the jaws and under the tail) and cultivated at $36^{\circ} \mathrm{C}$ (body temperature of Lama glama L.) on nutrient agar (Oxoid) in the presence or absence of blood for 24-48 h.

\section{Biotyping}

Gram-stained cell morphology and cell arrangement were determined on P agar (Kloos et al., 1992) after 24 h; colony morphology and pigment production were determined on $\mathrm{P}$ agar after $48-72 \mathrm{~h}$. Cell size was assessed after $24 \mathrm{~h}$ on nutrient agar (Oxoid). Haemolysis was tested on tryptic soy agar (Difco) with $5 \%$ sheep blood. Growth was observed on nutrient agar (Oxoid) at different salt concentrations $(4,7 \cdot 5$, 10 and $12 \% \mathrm{NaCl})$ at $36^{\circ} \mathrm{C}$ and at different temperatures $\left(4,15,36\right.$ and $\left.42^{\circ} \mathrm{C}\right)$. Anaerobic growth was observed in thioglycolate semi-solid medium (Oxoid). Hydrolysis of Tween 80, gelatin (Páčová \& Kocur, 1984), starch (Barrow \& Feltham, 1993) and casein (Kurup \& Babcock, 1979) and production of DNase (Oxoid), lecithinase (Owens, 1974) and catalase (Hanker \& Rabin, 1975) was tested. Acid production from glycerol, D-salicin, D-sorbitol, D-galactose and melezitose (Anonymous, 1965) was studied by conventional methods. Oxidase (OXI test, PlivaLachema), pyrrolidonyl arylamidase (Pliva-Lachema) and coagulase (Itest-Plus) activity and the presence of clumping factor (Pastorex Staph Plus) were determined by commercial tests. Further biochemical properties were tested using API STAPH, ID 32 Staph and API ZYM kits (bioMérieux) according to the manufacturer's instructions. Antibiotic susceptibility was determined by disc-diffusion (Woods \& Washington, 1995), involving incubation of cultures on
Mueller-Hinton agar (Oxoid) plates at $36^{\circ} \mathrm{C}$ for $24 \mathrm{~h}$ with a standard set of antibiotic discs for staphylococci (Sanofi Diagnostic Pasteur, Pliva-Lachema, Itest-Plus). The following antibiotics discs were used: furazolidone $(100 \mu \mathrm{g})$, bacitracin Taxo A $(0.04 \mathrm{U})$, clindamycin (5 IU), novobiocin $(1 \cdot 6 \mu \mathrm{g})$, novobiocin $(5 \mu \mathrm{g})$, oxacillin $(1 \mu \mathrm{g})$, trimethoprim/sulfamethoxazole $(1 \cdot 25 / 23 \cdot 75 \mu \mathrm{g})$, tetracycline $(30 \mu \mathrm{g})$, cephalothin $(30 \mu \mathrm{g})$, gentamicin $(10 \mu \mathrm{g})$, chloramphenicol $(30 \mu \mathrm{g})$, amoxicillin/clavulanic acid (20/ $10 \mu \mathrm{g})$, vancomycin $(30 \mu \mathrm{g})$ and piperacillin/tazobactam $(100 / 10 \mu \mathrm{g})$.

All strains were Gram-positive, catalase- and oxidasepositive cocci. Cells were arranged singly, in pairs and tetrads or in irregular clusters. Colonies grown at $36^{\circ} \mathrm{C}$ were 2-5 mm in diameter after $24 \mathrm{~h}$. Strains of M. brunensis sp. nov. and $M$. hajekii sp. nov. were non-pigmented; strains of $M$. lamae sp. nov. produced an orange pigment. None of the strains grew in the anaerobic portion of a thioglycolate semisolid medium. The strains were non-haemolytic on sheep blood (5\%) agar. Phenotypic properties to distinguish the newly isolated taxa and to differentiate them from previously described macrococci and phenotypically closely related staphylococci are summarized in Table 1. All three novel species of macrococci from llamas are clearly separated from other previously described macrococci by their phosphatase production, absence of acid production from glycerol and inability to grow in $7 \cdot 5 \% \mathrm{NaCl}$. Strains of the three novel species can be distinguished from each other by a combination of the following tests: acid production from sucrose, esterase-lipase production, growth in $4 \%$ $\mathrm{NaCl}$ and susceptibility to $5 \mu \mathrm{g}$ novobiocin (Table 1 ). All the strains isolated are susceptible to furazolidone and resistant to bacitracin. They were also susceptible to clindamycin, oxacillin, trimethoprim/sulfamethoxazole, tetracycline, cephalothin, chloramphenicol, amoxicillin/clavulanic acid, gentamicin, vancomycin and piperacillin/tazobactam.

\section{Phylogenetic analysis based on 165 rDNA sequences}

The 16S rRNA gene was amplified using primers U24 (5'-AGAGTTTGATCAGGGCTCAGGATG- ${ }^{\prime}$ ) and L20 (5'-AAGGAGGTGATCCAGCCGCA-3'). PCR was performed according to Švec et al. (2001a). Both strands of the amplified DNA were sequenced by dideoxynucleotide chain termination sequencing with primers U24 and L20 followed by primer walking with forward primers P1 (5'-TTCGGATCGTAAAACTCTGTTG-3') and P2 (5'-GATGGTACCAAGGGCAACGAAAC-3') and reverse primers P3 (5'-TCTCAGGTCGGCTACGCATCGTC-3') and P4 (5'-AATGATGGCAACTAAGGATAAGG-3'). Primer synthesis and DNA sequencing were performed according to Štěpán et al. (2001).

Calculations and data analyses were performed with PHYLIP version 3.6 (Felsenstein, 2001). For estimation of phylogenetic relationships among the species under study, a program was used that implements the maximum-likelihood 
Table 1. Characteristics useful for differentiation of $M$. brunensis sp. nov., $M$. hajekii sp. nov. and M. lamae sp. nov., related macrococci and oxidase-positive staphylococci

Species: 1, M. brunensis sp. nov.; 2, M. lamae sp. nov.; 3, M. hajekii sp. nov.; 4, M. caseolyticus; 5, M. carouselicus; 6, M. equipercicus; 7, M. bovicus (data in columns 4-7 from Kloos et al., 1998); 8, S. lentus (data from Kloos et al., 1976; Webster et al., 1994); 9, S. vitulinus (Webster et al., 1994; Kloos \& Bannerman, 1999); 10, S. sciuri subsp. rodentium; 11, S. sciuri subsp. sciuri; 12, S. sciuri subsp. carnaticus (data in columns 10-12 from Webster et al., 1994; Kloos et al., 1997). +, Positive; -, negative; d, variable reaction; ND, no data. The phenotypic profile for M. hajekii sp. nov. was determined on the basis of results for a single strain.

\begin{tabular}{|c|c|c|c|c|c|c|c|c|c|c|c|c|}
\hline Characteristic & 1 & 2 & 3 & 4 & 5 & 6 & 7 & 8 & 9 & 10 & 11 & 12 \\
\hline Resistance to novobiocin $(5 \mu \mathrm{g})$ & + & - & + & + & + & + & + & + & + & + & + & + \\
\hline \multicolumn{13}{|l|}{ Growth in: } \\
\hline $4 \% \mathrm{NaCl}$ & + & - & - & + & + & + & + & + & + & + & + & + \\
\hline \multicolumn{13}{|l|}{ Acid from: } \\
\hline Glycerol & - & - & - & $\mathrm{d}$ & $\mathrm{d}$ & + & + & + & + & + & + & + \\
\hline Sucrose & - & + & + & $\mathrm{d}$ & $\mathrm{d}$ & $\mathrm{d}$ & $\mathrm{d}$ & + & + & + & + & + \\
\hline D-Cellobiose & - & - & - & - & - & - & - & + & $\mathrm{d}$ & $\mathrm{d}$ & + & $\mathrm{d}$ \\
\hline \multicolumn{13}{|l|}{ Hydrolysis of: } \\
\hline Aesculin & - & - & - & $\mathrm{d}$ & + & $\mathrm{d}$ & $\mathrm{d}$ & + & $\mathrm{d}$ & + & + & + \\
\hline
\end{tabular}

method for DNA sequences implementing the Hidden Markov Model method of inferring different rates of evolution of different sites (Felsenstein \& Churchill, 1996).

The 16S rDNA sequences of type strains from each proposed macrococcal species were determined and compared with $16 \mathrm{~S}$ rDNA sequences of other species of macrococci, oxidase-positive species of staphylococci and selected oxidase-negative staphylococci (Fig. 1). The phylogenetic positions on the tree confirm that the type strains of M. brunensis sp. nov., M. hajekii sp. nov. and M. lamae sp. nov. are members of the genus Macrococcus. Levels of $16 \mathrm{~S}$ rDNA sequence similarity among the newly described species are in the range found in known macrococcal species, 98-99\%, except for M. caseolyticus, which shows lower similarity of only $97 \%$. Most differences in the $16 \mathrm{~S}$ rDNA sequence (predominate transitions) were found in the region 61-228. The sequences of $M$. brunensis CCM $4811^{\mathrm{T}}$ and $M$. bovicus CCM $4655^{\mathrm{T}}$ are characterized by two $1 \mathrm{nt}$ deletions at positions 72 and 84 , where $\mathrm{A}$ and/or $\mathrm{T}$ are present in the other macrococcal species. In M. lamae CCM $4815^{\mathrm{T}}$ and $M$. brunensis CCM $4811^{\mathrm{T}}$, there is a $1 \mathrm{nt}$ insertion of $\mathrm{G}$ at position 217. The sequence of $M$. hajekii CCM $4809^{\mathrm{T}}$ differs from the other species in a $1 \mathrm{nt}$ insertion at position 568 and is closely related to the sequences of $M$. equipercicus CCM $4653^{\mathrm{T}}$ and M. carouselicus CCM $4650^{\mathrm{T}}$.

\section{Ribotyping}

Isolation of genomic DNA and ribotyping were performed according to Švec et al. (2001b), modified only by using brain heart infusion broth (Oxoid) for cultivation. Hybridization profile analysis and cluster analysis were done using GelCompar II software (Applied Maths). The dendrogram was calculated by UPGMA clustering using the Jaccard coefficient.

The dendrogram (Fig. 2) shows ribotyping (EcoRI) results of representative strains selected from all species analysed. Ribotyping clearly separated the macrococci and staphylococci (similarity was only $17 \%$ ). Furthermore, the hybridization profiles of all the macrococcal species are clearly distinguished. All three M. lamae strains have identical hybridization profiles. The M. brunensis strains formed one cluster, with $75 \%$ similarity. The profile of $M$. hajekii confirmed its separate position.

\section{Fatty acid methyl ester (FAME) analysis}

Cultures were grown for $24 \mathrm{~h}$ at $28^{\circ} \mathrm{C}$ on plates containing $30 \mathrm{~g}$ trypticase soy broth (BBL) supplemented with $15 \mathrm{~g}$ Bacto agar (Difco) $1^{-1}$ distilled water. Cells were saponified, methylated to FAMEs and extracted following the Sherlock Microbial Identification System version 3.0 (MIDI, 1999). FAMEs were separated on an Agilent 6890A series gas chromatograph with 7683 autoinjector and autosampler tray module (Agilent Technologies). Separation of FAMEs was achieved with a fused-silica capillary column $(25 \mathrm{~m}$ by $0.2 \mathrm{~mm}$ ) with cross-linked $5 \%$ phenylmethyl silicone (film thickness $0.33 \mu \mathrm{m}$; HP Ultra2). $\mathrm{H}_{2}$ served as carrier gas. Peak integration and identification were performed using 


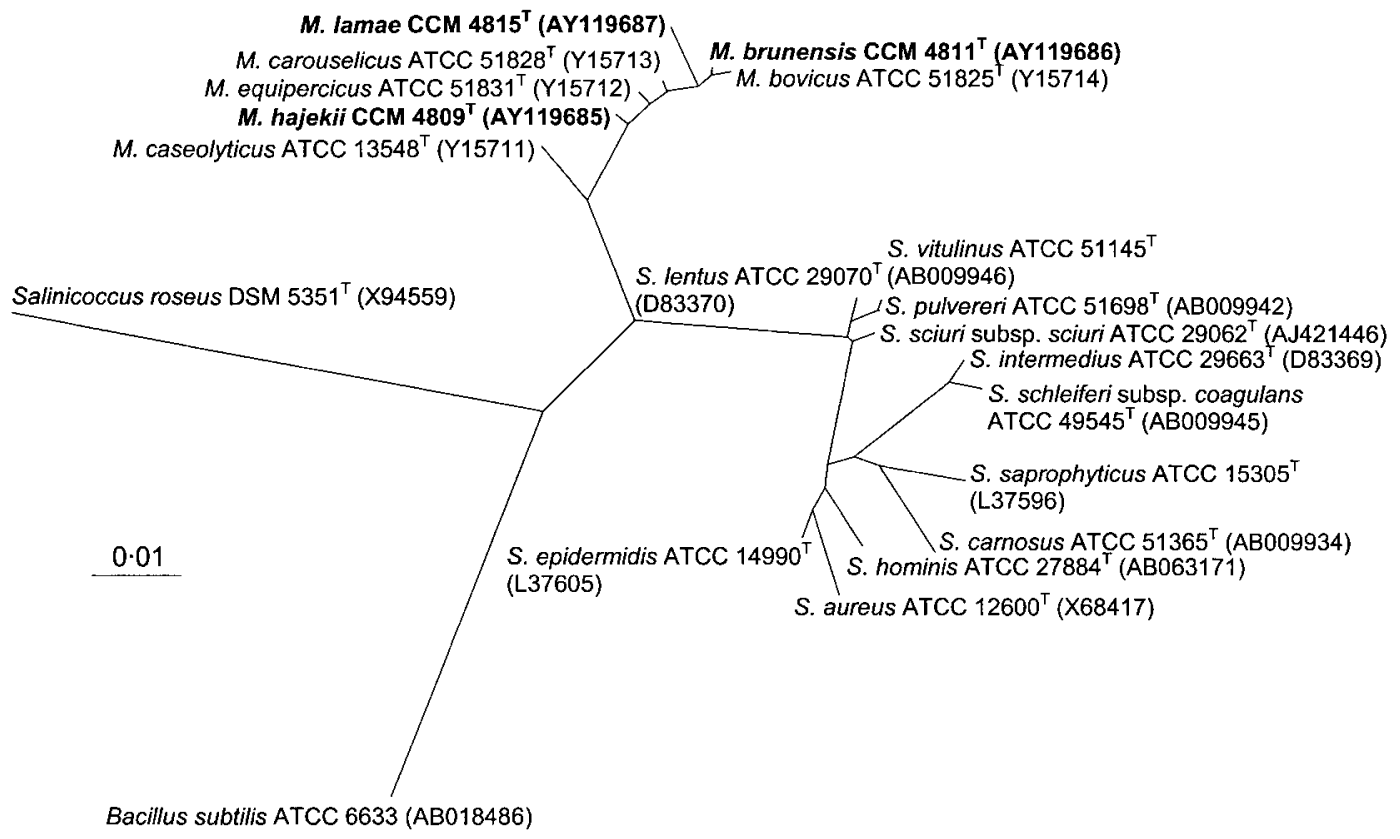

Fig. 1. Phylogenetic tree constructed on the basis of $16 \mathrm{~S}$ rDNA sequences shows the relationship between $M$. brunensis sp. nov., M. hajekii sp. nov. and $M$. lamae sp. nov., previously described macrococci, oxidase-positive staphylococci and selected oxidase-negative staphylococci. S., Staphylococcus. GenBank accession numbers are given in parentheses.

the Hewlett Packard Chemstation software and Sherlock software.

The results of this analysis are summarized in Table 2 . The novel macrococcal species differ from one another and from previously described species in the composition and percentages of FAMEs. Among the novel taxa, M. brunensis and $M$. hajekii strains contain predominantly saturated branched-chain (anteiso-15:0 and iso-15:0) and unsaturated straight-chain $(18: 1 \omega 9 c, 16: 1 \omega 11 c$ and iso$17: 1 \omega 10 c)$ fatty acids. M. lamae strains contain predominantly saturated branched-chain (iso-15:0) and saturated straight-chain $(16: 0,14: 0$ and $20: 0)$ fatty acids.

\section{Macrorestriction pattern analysis}

Preparation of chromosomal DNAs, digestion with XbaI, NotI and SmaI (Roche Diagnostics) and macrorestriction
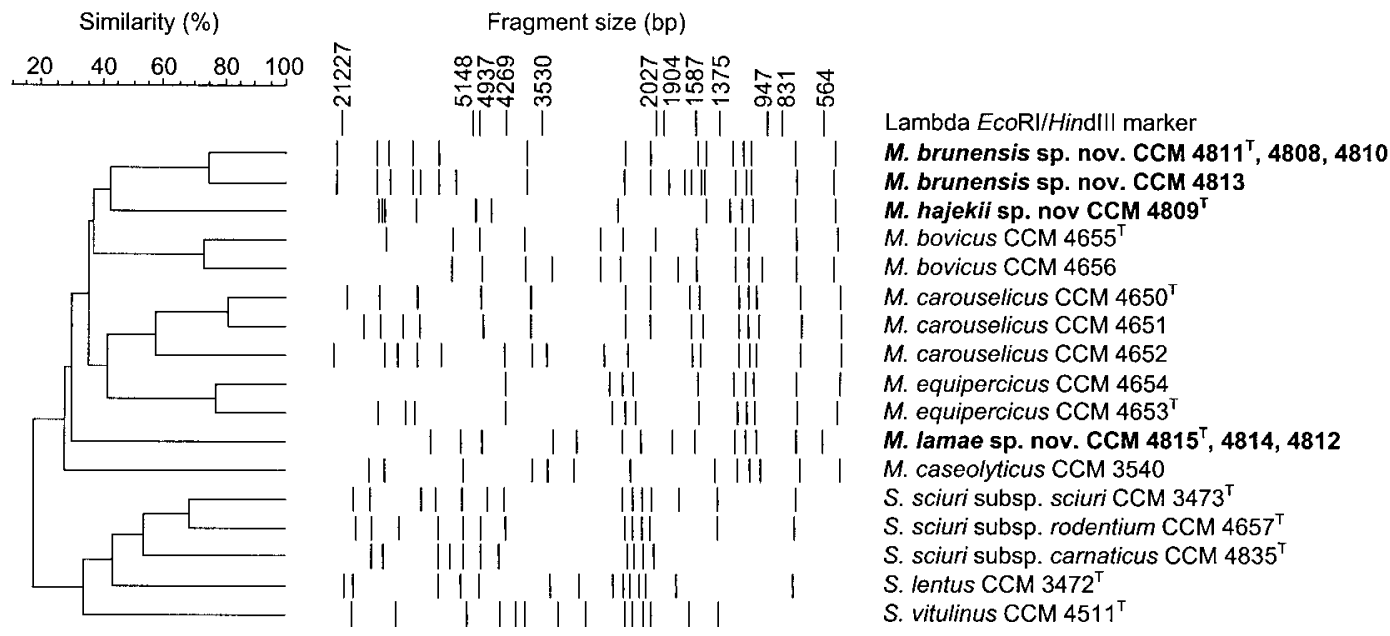

Fig. 2. Dendrogram of ribotyping (EcoRl) profiles of $M$. brunensis sp. nov., M. hajekii sp. nov. and M. lamae sp. nov. and other macrococcal species and oxidase-positive staphylococci. 
Table 2. Fatty acid contents of whole-cell hydrolysates of Macrococcus strains

Strains: 1-4, M. brunensis sp. nov. strains CCM 4808 (1), CCM 4810 (2), CCM 4811 ${ }^{\mathrm{T}}$ (3) and CCM 4813 (4); 5, M. hajekii sp. nov. CCM $4809^{\mathrm{T}}$; 6-8, M. lamae sp. nov. strains CCM 4812 (6), CCM 4814 (7) and CCM $4815^{\mathrm{T}}$ (8); 9, M. bovicus CCM 4655 ${ }^{\mathrm{T}}$; 10, M. caseolyticus CCM $3540^{\mathrm{T}}$; 11, M. carouselicus CCM $4650^{\mathrm{T}} ; 12$, M. equipercicus CCM $4653^{\mathrm{T}}$. Values are mean percentages of total FAMEs. Only fatty acids accounting for more than $1.0 \%$ (mean amount) are indicated. -, Not detected; tr, trace amount $(<1 \cdot 0 \%)$. TBSA, Tuberculostearic acid (10-methyl-18:0).

\begin{tabular}{|c|c|c|c|c|c|c|c|c|c|c|c|c|}
\hline Strain & 1 & 2 & 3 & 4 & 5 & 6 & 7 & 8 & 9 & 10 & 11 & 12 \\
\hline anteiso- $13: 0$ & $\operatorname{tr}$ & $\operatorname{tr}$ & $1 \cdot 1$ & $\operatorname{tr}$ & $\operatorname{tr}$ & $\operatorname{tr}$ & $\operatorname{tr}$ & $1 \cdot 3$ & $\operatorname{tr}$ & - & $\operatorname{tr}$ & - \\
\hline iso- $14: 0$ & $1 \cdot 8$ & $1 \cdot 7$ & $1 \cdot 8$ & $1 \cdot 3$ & $2 \cdot 0$ & $1 \cdot 9$ & $1 \cdot 6$ & $1 \cdot 7$ & $1 \cdot 3$ & $7 \cdot 9$ & $2 \cdot 0$ & $1 \cdot 1$ \\
\hline iso-15:0 & $14 \cdot 5$ & $11 \cdot 9$ & $12 \cdot 6$ & $13 \cdot 4$ & $16 \cdot 0$ & $22 \cdot 1$ & $17 \cdot 2$ & $26 \cdot 1$ & $10 \cdot 4$ & - & $4 \cdot 9$ & $24 \cdot 7$ \\
\hline anteiso- $15: 0$ & $30 \cdot 6$ & $23 \cdot 2$ & $21 \cdot 1$ & $24 \cdot 7$ & $19 \cdot 8$ & $7 \cdot 2$ & $5 \cdot 7$ & $9 \cdot 2$ & $18 \cdot 8$ & - & $1 \cdot 9$ & $31 \cdot 8$ \\
\hline $16: 0$ & $\operatorname{tr}$ & $2 \cdot 3$ & $2 \cdot 6$ & $2 \cdot 6$ & $1 \cdot 3$ & $13 \cdot 6$ & $16 \cdot 8$ & $11 \cdot 1$ & $6 \cdot 0$ & $6 \cdot 6$ & $13 \cdot 6$ & $\operatorname{tr}$ \\
\hline Summed feature $4^{\star}$ & $4 \cdot 5$ & $2 \cdot 1$ & $1 \cdot 9$ & $2 \cdot 2$ & $1 \cdot 4$ & - & - & - & $1 \cdot 6$ & - & - & $12 \cdot 5$ \\
\hline $16: 1 \omega 11 c$ & $7 \cdot 8$ & $12 \cdot 6$ & $6 \cdot 5$ & $9 \cdot 1$ & $16 \cdot 4$ & $5 \cdot 4$ & $6 \cdot 1$ & $6 \cdot 0$ & $4 \cdot 6$ & $29 \cdot 5$ & $18 \cdot 0$ & $1 \cdot 3$ \\
\hline $16: 1 \omega 7 c$ alcohol & $\operatorname{tr}$ & - & $\operatorname{tr}$ & - & - & - & - & - & - & $\operatorname{tr}$ & - & $2 \cdot 6$ \\
\hline 16:0 $\mathrm{N}$ alcohol & $1 \cdot 0$ & $1 \cdot 3$ & $\operatorname{tr}$ & $1 \cdot 1$ & $1 \cdot 0$ & - & - & - & $1 \cdot 2$ & - & $6 \cdot 9$ & - \\
\hline $18: 1 \omega 9 c$ & $10 \cdot 6$ & $20 \cdot 0$ & $22 \cdot 4$ & $19 \cdot 4$ & $18 \cdot 8$ & $1 \cdot 9$ & $1 \cdot 8$ & $1 \cdot 6$ & $16 \cdot 0$ & $32 \cdot 6$ & $17 \cdot 1$ & $\operatorname{tr}$ \\
\hline $18: 3 \omega 6 c$ & $\operatorname{tr}$ & $\operatorname{tr}$ & $1 \cdot 1$ & $1 \cdot 4$ & $3 \cdot 3$ & - & - & - & $5 \cdot 5$ & - & $8 \cdot 2$ & - \\
\hline TBSA & $1 \cdot 6$ & $1 \cdot 3$ & $1 \cdot 8$ & $1 \cdot 1$ & $\operatorname{tr}$ & - & - & - & $2 \cdot 0$ & - & - & $3 \cdot 1$ \\
\hline $20: 0$ & $\operatorname{tr}$ & $1 \cdot 5$ & $2 \cdot 6$ & $1 \cdot 8$ & - & $12 \cdot 8$ & $13 \cdot 0$ & $9 \cdot 7$ & $2 \cdot 4$ & - & $1 \cdot 1$ & $\operatorname{tr}$ \\
\hline $20: 1 \omega 9 c$ & $1 \cdot 6$ & $1 \cdot 1$ & $1 \cdot 4$ & $1 \cdot 2$ & $\operatorname{tr}$ & - & $\operatorname{tr}$ & - & - & $2 \cdot 0$ & - & $\operatorname{tr}$ \\
\hline
\end{tabular}

* Summed feature 4 consists of one or more of the following fatty acids, which could not be separated by the Microbial Identification System: $17: 1$ iso I, $17: 1$ anteiso B.

pattern analysis were performed as described by Pantůček et al. (1999) with the following modifications. The CHEFMapper (Bio-Rad) and multistate program conditions were: field inversion gel electrophoresis with increasing pulse times of 0.05 to $1.0 \mathrm{~s}$ for $7 \mathrm{~h}$ with forward and reverse voltage 8.5 and $5.5 \mathrm{~V} \mathrm{~cm}^{-1}$, respectively, followed by standard PFGE with reorientation angle $120^{\circ}$, pulse times $4 \cdot 0-20 \cdot 0 \mathrm{~s}$ and voltage $5 \cdot 5 \mathrm{~V} \mathrm{~cm}{ }^{-1}$ for $17 \mathrm{~h}$. Concatemers of lambda phage DNA (Sigma) and molecular mass markers II and X (Roche Diagnostics) were used as size standards.

NotI cleaved the chromosomes of the newly proposed macrococcal species into small numbers of fragments (2-8), so the results were unsuitable for similarity determination. SmaI cleaved them into a larger number of fragments, showing substantial size differences in comparison with other macrococcal species. Restriction endonuclease XbaI was the most satisfactory, since it cleaved all the macrococcal chromosomes into 30-50 fragments that exhibited comparable size ranges; comparison of profiles demonstrated that M. brunensis, M. lamae and M. hajekii strains differed from the type strains of previously described macrococcal species (Fig. 3). All four strains of M. brunensis (CCM 4808, CCM
4810, CCM $4811^{\mathrm{T}}$ and CCM 4813) had very similar macrorestriction patterns (98-99\% similarity), differing in only one or two fragments. Likewise, the three M. lamae

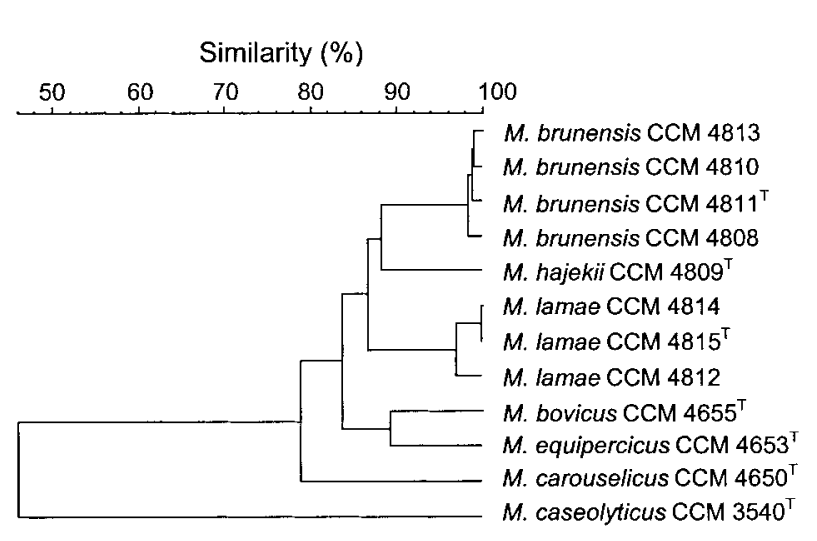

Fig. 3. Dendrogram based on cluster analysis of macrorestriction fragments of $M$. brunensis sp. nov., M. hajekii sp. nov., $M$. lamae sp. nov. and type strains of previously described Macrococcus species. 
strains formed one cluster with similarities of $97-100 \%$. M. hajekii CCM $4809^{\mathrm{T}}$ showed unique macrorestriction patterns, different from those of M. brunensis and M. lamae strains.

\section{DNA base compositions}

DNA was isolated as described for DNA-DNA hybridization and degraded enzymically into nucleosides as described by Mesbah et al. (1989). The nucleoside mixture obtained was then separated by HPLC using a Waters Symmetry Shield $\mathrm{C} 8$ column at $37^{\circ} \mathrm{C}$. The solvent was $0.02 \mathrm{M} \mathrm{NH}_{4} \mathrm{H}_{2} \mathrm{PO}_{4}$ $(\mathrm{pH} 4 \cdot 0)$ with $1.5 \%$ acetonitrile. Non-methylated lambda phage DNA (Sigma) was used as calibration reference.

The $\mathrm{G}+\mathrm{C}$ contents of the newly isolated strains ranged from 40 to $42 \mathrm{~mol} \%$, values which are within the range of those described for Macrococcus species (Kloos et al., 1998) (Table 3). These values are higher than those of staphylococcal species (30-39 mol\%; Kloos et al., 1992) and significantly lower than those of other Gram-positive, oxidase- and catalase-positive cocci belonging to genera such as Kocuria, Dermacoccus, Kytococcus, Micrococcus and Deinococcus, in which the $\mathrm{G}+\mathrm{C}$ content is $62-76 \mathrm{~mol} \%$ (Kloos et al., 1992, 1998; Murray, 1992; Stackebrandt et al., 1995).

\section{DNA-DNA hybridization}

The strains were cultivated on nutrient agar (Oxoid) at $28^{\circ} \mathrm{C}$ for $24 \mathrm{~h}$ with the exception of M. carouselicus CCM $4650^{\mathrm{T}}$, which was cultivated in trypticase soy broth (BBL) at $28^{\circ} \mathrm{C}$ for $7 \mathrm{~h}$. DNA was extracted from $0 \cdot 75-1 \cdot 25 \mathrm{~g}$ wet weight of cells using the protocol described by Pitcher et al. (1989) with the following modifications. For strains $M$. caseolyticus CCM $3540^{\mathrm{T}}$, M. equipercicus CCM 4653 ${ }^{\mathrm{T}}$, M. hajekii CCM $4809^{\mathrm{T}}$, M. brunensis CCM $4811^{\mathrm{T}}$ and CCM 4813 and M. lamae CCM $4815^{\mathrm{T}}$, the washed cell pellet was resuspended and lysed in a buffer $(10 \mathrm{mM}$ Tris/ $\mathrm{HCl}$, $100 \mathrm{mM}$ EDTA, pH 8.0) containing RNase $\left(200 \mu \mathrm{g} \mathrm{ml}^{-1}\right.$; Sigma), mutanolysin (100 $\mathrm{U} \mathrm{ml}^{-1}$; Sigma) and lysozyme (25 mg ml${ }^{-1}$; SERVA) for $1 \mathrm{~h} \mathrm{at} 37^{\circ} \mathrm{C}$. For strains
M. bovicus CCM $4655^{\mathrm{T}}$ and M. carouselicus CCM $4650^{\mathrm{T}}$, lysostaphin (120 $\mathrm{U} \mathrm{ml}^{-1}$; Sigma) was used instead of mutanolysin. Before addition of GES reagent, proteinase $\mathrm{K}\left(200 \mu \mathrm{g} \mathrm{ml}^{-1}\right.$; Merck) was added to the mixture for 15 min. DNA-DNA hybridizations were performed using a modification of the microplate method described by Ezaki et al. (1989), using an HTS7000 Bio Assay Reader (Perkin Elmer) for the fluorescence measurements. Biotinylated DNA was hybridized with single-stranded unlabelled DNA, non-covalently bound to microplate wells. Hybridizations were performed at $35^{\circ} \mathrm{C}$ in hybridization mixture $(2 \times \mathrm{SSC}$, $5 \times$ Denhardt's solution, $2.5 \%$ dextran sulfate, $50 \%$ formamide, $100 \mu \mathrm{g}$ denatured salmon sperm DNA ml ${ }^{-1}$ and $1250 \mathrm{ng}$ biotinylated probe DNA $\mathrm{ml}^{-1}$ ).

The DNA-DNA hybridization results are shown in Table 3. Representative strains from each phenotypic and ribotyping group were chosen to perform DNA-DNA hybridization experiments. The DNA-DNA relatedness values between previously described and newly proposed macrococcal species were lower than $54 \%$. These data confirmed that the strains from llamas represent three novel species.

\section{Description of Macrococcus brunensis sp. nov.}

Macrococcus brunensis (bru.nen'sis. L. adj. brunensis from Bruna, the Roman name of the city of Brno, Czech Republic, where the type strain was isolated).

Colonies reach $2-4 \mathrm{~mm}$ in diameter on $\mathrm{P}$ agar after $24 \mathrm{~h}$. Cell diameter is $0.89-1 \cdot 21 \mu \mathrm{m}$. Colonies are circular, smooth and glossy, without pigment. Growth is detected under anaerobic conditions at $15-36^{\circ} \mathrm{C}$ and in $4 \% \mathrm{NaCl}$ but not at 4 or $42^{\circ} \mathrm{C}$. All strains hydrolyse casein and gelatin, but not Tween 80, starch, lecithin, aesculin or tyrosine. Alkaline and acid phosphatases are produced, nitrates are reduced and acid is produced from maltose, D-mannitol, D-fructose, D-trehalose and D-glucose. Acetoin, clumping factor and coagulase are not produced and activities of urease, haemolysis, arginine dihydrolase, arginine arylamidase, ornithine decarboxylase, $\beta$-galactosidase, $\beta$-glucuronidase, pyrrolidonyl arylamidase, esterase (C4), lipase (C14),

Table 3. $\mathrm{G}+\mathrm{C}$ contents and DNA-DNA hybridization values of Macrococcus strains

\begin{tabular}{|c|c|c|c|c|c|c|c|c|c|}
\hline \multirow[t]{2}{*}{ Strain } & \multirow[t]{2}{*}{ DNA G $+C$ content $(\mathrm{mol} \%)$} & \multicolumn{8}{|c|}{ DNA-DNA hybridization with DNA from: (\%) } \\
\hline & & 1 & 2 & 3 & 4 & 5 & 6 & 7 & 8 \\
\hline 2. M. carouselicus CCM $4650^{\mathrm{T}}$ & $41^{\star}$ & 40 & 100 & & & & & & \\
\hline 3. M. caseolyticus CCM $3540^{\mathrm{T}}$ & 37 & 13 & 17 & 100 & & & & & \\
\hline 4. M. equipercicus CCM $4653^{\mathrm{T}}$ & 44 & 25 & 33 & 16 & 100 & & & & \\
\hline 6. M. brunensis CCM $4811^{\mathrm{T}}$ & 42 & 54 & 49 & 19 & 26 & 34 & 100 & & \\
\hline 7. M. brunensis CCM 4813 & 42 & 53 & 45 & 20 & 28 & 35 & 100 & 100 & \\
\hline 8. M. lamae CCM $4815^{\mathrm{T}}$ & 41 & 29 & 30 & 16 & 37 & 23 & 30 & 28 & 100 \\
\hline
\end{tabular}

${ }^{\star}$ Data from Kloos et al. (1998). 
naphthol-AS-BI-phosphohydrolase, valine arylamidase, cystine arylamidase, $\alpha$-galactosidase, $N$-acetyl $\beta$-glucosaminidase, $\alpha$-mannosidase, $\alpha$-fucosidase and esterase-lipase (C8) are negative. Acid is not produced from sucrose, melezitose, xylose, arabinose, turanose, xylitol, D-sorbitol, D-cellobiose, D-salicin, raffinose, D-galactose, lactose, ribose, D-melibiose, D-mannose, $N$-acetylglucosamine or methyl $\alpha$-D-glucoside. All strains are resistant to novobiocin. Predominant fatty

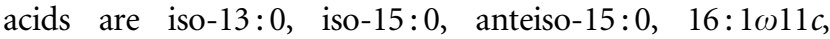
iso-17: $1 \omega 10 c$ and $18: 1 \omega 9 c$ (Table 2). The $\mathrm{G}+\mathrm{C}$ content of the DNA is $41-42 \mathrm{~mol} \%$.

The type strain, CCM $4811^{\mathrm{T}}$ ( $=$ LMG $21712^{\mathrm{T}}$ ), was isolated from llama skin. Its characteristics are in full agreement with the species description. The $\mathrm{G}+\mathrm{C}$ content of the DNA is $42 \mathrm{~mol} \%$.

\section{Description of Macrococcus hajekii sp. nov.}

Macrococcus hajekii (ha.je'ki.i. N.L. gen. n. hajekii of Hájek, named after Václav Hájek, a Czech microbial taxonomist).

Colonies reach $2-3 \mathrm{~mm}$ in diameter on $\mathrm{P}$ agar after $24 \mathrm{~h}$. Mean cell diameter is $0.89 \mu \mathrm{m}$. Colonies are circular, smooth and glossy, without pigment. Does not grow at 4 or $42{ }^{\circ} \mathrm{C}$ or in $4 \% \mathrm{NaCl}$, but grows at $15-36^{\circ} \mathrm{C}$. Hydrolyses casein and gelatin, but not Tween 80 , starch, lecithin, aesculin or tyrosine. Alkaline phosphatase is produced, nitrates are reduced and acid is produced from sucrose, maltose, D-mannitol, D-fructose, D-trehalose and D-glucose. Acetoin, clumping factor and coagulase are not produced and activities of urease, haemolysis, arginine dihydrolase, arginine arylamidase, ornithine decarboxylase, $\beta$-galactosidase, $\beta$-glucuronidase, pyrrolidonyl arylamidase, esterase (C4), lipase (C14), naphthol-AS-BI-phosphohydrolase, valine arylamidase, cystine arylamidase, $\alpha$-galactosidase, $N$ acetyl- $\beta$-glucosaminidase, $\alpha$-mannosidase, $\alpha$-fucosidase, esterase-lipase (C8) and acid phosphatase are negative. Acid is not produced from melezitose, xylose, arabinose, turanose, D-sorbitol, D-cellobiose, xylitol, D-salicin, raffinose, D-galactose, lactose, ribose, D-melibiose, D-mannose, $N$-acetylglucosamine or methyl $\alpha$-D-glucoside. Resistant to novobiocin. Dominant fatty acids are iso- $13: 0$, iso- $15: 0$,

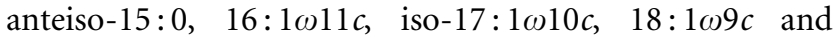
$18: 3 \omega 6 c$ (Table 2). The $\mathrm{G}+\mathrm{C}$ content of the DNA is $40 \mathrm{~mol} \%$.

The type strain, CCM $4809^{\mathrm{T}}\left(=\mathrm{LMG} 21711^{\mathrm{T}}\right)$, was isolated from llama skin.

\section{Description of Macrococcus lamae sp. nov.}

Macrococcus lamae (la' mae. N.L. fem. gen. n. lamae of Lama, the zoological genus name of the llama).

Colonies reach $2-5 \mathrm{~mm}$ in diameter on $\mathrm{P}$ agar after $24 \mathrm{~h}$. Cell diameter is $0.74-0.92 \mu \mathrm{m}$. Colonies are circular, smooth and glossy and have an orange pigment. All the strains tested grow at $15-36{ }^{\circ} \mathrm{C}$. Growth is not detected under anaerobic conditions, in $4 \% \mathrm{NaCl}$ or at 4 or $42^{\circ} \mathrm{C}$.
Strains hydrolyse casein and gelatin, but not Tween 80, starch, lecithin, aesculin or tyrosine. Alkaline phosphatase and esterase-lipase (C8) are produced. Acid is produced from sucrose, maltose, D-mannitol, D-fructose, D-trehalose and D-glucose. Acetoin, clumping factor and coagulase are not produced and activities of urease, haemolysis, arginine dihydrolase, arginine arylamidase, ornithine decarboxylase, $\beta$-galactosidase, $\beta$-glucuronidase, pyrrolidonyl arylamidase, esterase (C4), lipase (C14), naphthol-AS-BIphosphohydrolase, valine arylamidase, cystine arylamidase, $\alpha$-galactosidase, $N$-acetyl- $\beta$-glucosaminidase, $\alpha$-mannosidase, $\alpha$-fucosidase are not observed. Nitrate is not reduced. Acid is not produced from melezitose, xylose, arabinose, turanose, Dsorbitol, D-cellobiose, D-salicin, raffinose, xylitol, D-galactose, lactose, ribose, D-melibiose, D-mannose, $N$-acetylglucosamine or methyl $\alpha$-D-glucoside. Strain CCM 4812 does not produce acid phosphatase. Susceptible to novobiocin $(5 \mu \mathrm{g})$ and intermediate susceptibility to novobiocin $(1 \cdot 6 \mu \mathrm{g})$. Predominant fatty acids are iso-13:0, $14: 0$, iso- $15: 0$, anteiso-

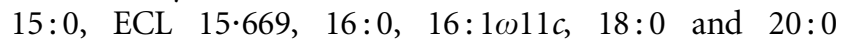
(Table 2). The G+C content of the DNA is $41-42 \mathrm{~mol} \%$.

The type strain, CCM $4815^{\mathrm{T}}$ ( = LMG $21713^{\mathrm{T}}$ ), was isolated from llama skin. Its characteristics are in full agreement with the species description. The $\mathrm{G}+\mathrm{C}$ content of the DNA is $41 \mathrm{~mol} \%$.

\section{Acknowledgements}

We would like to thank to Anthony Long for English correction of the manuscript. Special thanks to H. G. Trüper for checking the nomenclature. This study was partially supported by the projects of the Grant Agency of the Czech Republic (project numbers 301/02/1505 and 204/02/D099) and by long-term research program no. MSM143100008 of the Ministry of Education of the Czech Republic.

\section{References}

Anonymous (1965). Subcommittee on taxonomy of staphylococci and micrococci. Recommendations. Int Bull Bacteriol Nomencl Taxon 15, 109-110.

Baker, J. S. (1984). Comparison of various methods for differentiation of staphylococci and micrococci. J Clin Microbiol 19, 875-879.

Barrow, G. I. \& Feltham, R. K. A. (1993). Cowan and Steel's Manual for the Identification of Medical Bacteria, 2nd edn. Cambridge: Cambridge University Press.

Ezaki, T., Hashimoto, Y. \& Yabuuchi, E. (1989). Fluorometric deoxyribonucleic acid-deoxyribonucleic acid hybridization in microdilution wells as an alternative to membrane filter hybridization in which radioisotopes are used to determine genetic relatedness among bacterial strains. Int J Syst Bacteriol 39, 224-229.

Falk, D. \& Guering, S. J. (1983). Differentiation of Staphylococcus and Micrococcus spp. with the Taxo A bacitracin disk. J Clin Microbiol 18, 719-721.

Felsenstein, J. (2001). PHYLIP: phylogeny inference package. Department of Genetics, University of Washington, Seattle, USA. http://evolution.genetics.washington.edu/phylip.html.

Felsenstein, J. \& Churchill, G. A. (1996). A Hidden Markov Model approach to variation among sites in rate of evolution. Mol Biol Evol 13, 93-104. 
Hanker, J. S. \& Rabin, A. N. (1975). Color reaction streak test for catalase-positive microorganisms. J Clin Microbiol 2, 463-464.

Kloos, W. E. \& Bannerman, T. L. (1999). Staphylococcus and Micrococcus. In Manual of Clinical Microbiology, 7th edn, pp. 264-282. Edited by P. R. Murray, E. J. Baron, M. A. Pfaller, F. C. Tenover \& R. H. Yolken. Washington, DC: American Society for Microbiology.

Kloos, W. E., Schleifer, K. H. \& Smith, R. F. (1976). Characterization of Staphylococcus sciuri sp. nov. and its subspecies. Int J Syst Bacteriol 26, 22-37.

Kloos, W. E., Schleifer, K. H. \& Götz, F. (1992). The genus Staphylococcus. In The Prokaryotes: a Handbook on the Biology of Bacteria. Ecophysiology, Isolation, Identification, Applications, 2nd edn, vol. 2, pp. 1369-1403. Edited by A. Balows, H. G. Trüper, M. Dworkin, W. Harder \& K. H. Schleifer. New York: Springer.

Kloos, W. E., Ballard, D. N., Webster, J. A. \& 12 other authors (1997). Ribotype delineation and description of Staphylococcus sciuri subspecies and their potential as reservoirs of methicillin resistance and staphylolytic enzyme genes. Int J Syst Bacteriol 47, 313-323.

Kloos, W. E., Ballard, D. N., George, C. G., Webster, J. A., Hubner, R. J., Ludwig, W., Schleifer, K. H., Fiedler, F. \& Schubert, K. (1998). Delimiting the genus Staphylococcus through description of Macrococcus caseolyticus gen. nov., comb. nov. and Macrococcus equipercicus sp. nov., Macrococcus bovicus sp. nov. and Macrococcus carouselicus sp. nov. Int J Syst Bacteriol 48, 859-877.

Kurup, V. P. \& Babcock, J. B. (1979). Use of casein, tyrosine, and hypoxanthine in the identification of nonfermentative Gramnegative bacilli. Med Microbiol Immunol 167, 71-75.

Mesbah, M., Premachandran, U. \& Whitman, W. B. (1989). Precise measurement of the $\mathrm{G}+\mathrm{C}$ content of deoxyribonucleic acid by high-performance liquid chromatography. Int J Syst Bacteriol 39, 159-167.

MIDI (1999). Sherlock Microbial Identification System Operating Manual, version 3. Newark, DE: MIDI Inc.

Murray, R. G. E. (1992). The genus Deinococcus. In The Prokaryotes: a Handbook on the Biology of Bacteria. Ecophysiology, Isolation, Identification, Applications, 2nd edn, vol. 2, pp. 1369-1403. Edited by A. Balows, H. G. Trüper, M. Dworkin, W. Harder \& K. H. Schleifer. New York: Springer.

Owens, J. J. (1974). The egg yolk reaction produced by several species of bacteria. J Appl Bacteriol 37, 137-148.
Páčová, Z. \& Kocur, M. (1984). New medium for detection of esterase and gelatinase activity. Zentbl Bakteriol Mikrobiol Hyg A 258, 69-73.

Pantůček, R., Sedláček, I., Doškar̆, J. \& Rosypal, S. (1999). Complex genomic and phenotypic characterization of the related species Staphylococcus carnosus and Staphylococcus piscifermentans. Int J Syst Bacteriol 49, 941-951.

Pitcher, D. G., Saunders, N. A. \& Owen, R. J. (1989). Rapid extraction of bacterial genomic DNA with guanidium thiocyanate. Lett Appl Microbiol 8, 151-156.

Schleifer, K. H., Kilpper-Bälz, R., Fischer, U., Faller, A. \& Endl, J. (1982). Identification of "Micrococcus candidus" ATCC 14852 as a strain of Staphylococcus epidermidis and of "Micrococcus caseolyticus" ATCC 13548 and Micrococcus varians ATCC 29750 as members of a new species, Staphylococcus caseolyticus. Int J Syst Bacteriol 32, 15-20.

Stackebrandt, E., Koch, C., Gvozdiak, O. \& Schumann, P. (1995). Taxonomic dissection of the genus Micrococcus: Kocuria gen. nov., Nesterenkonia gen. nov., Kytococcus gen. nov., Dermacoccus gen. nov., and Micrococcus Cohn 1872 gen. emend. Int J Syst Bacteriol 45, 682-692.

Štěpán, J., Pantůček, R., Růžičková, V., Rosypal, S., Hájek, V. \& Doškař, J. (2001). Identification of Staphylococcus aureus based on PCR amplification of species specific genomic $826 \mathrm{bp}$ sequence derived from a common 44-kb SmaI restriction fragment. Mol Cell Probes 15, 249-257.

Švec, P., Devriese, L. A., Sedláček, I., Baele, M., Vancanneyt, M., Haesebrouck, F., Swings, J. \& Doškar̆, J. (2001a). Enterococcus haemoperoxidus sp. nov and Enterococcus moraviensis sp. nov. isolated from water. Int J Syst Evol Microbiol 51, 1567-1574.

Švec, P., Sedláček, I., Pantůček, R., Devriese, L. A. \& Doškař, J. V. (2001b). Evaluation of ribotyping for characterization and identification of Enterococcus haemoperoxidus and Enterococcus moraviensis strains. FEMS Microbiol Lett 203, 23-27.

Webster, J. A., Bannerman, T. L., Hubner, R. J., Ballard, D. N., Cole, E. M., Bruce, J. L., Fiedler, F., Schubert, K. \& Kloos, W. E. (1994). Identification of the Staphylococcus sciuri species group with EcoRI fragments containing rRNA sequences and description of Staphylococcus vitulus sp. nov. Int J Syst Bacteriol 44, 454-460.

Woods, G. L. \& Washington, J. A. (1995). Antibacterial susceptibility tests: dilution and disk-diffusion methods. In Manual of Clinical Microbiology, 6th edn, pp. 1327-1341. Edited by P. R. Murray, E. J. Baron, M. A. Pfaller, F. C. Tenover \& R. H. Yolken. Washington, DC: American Society for Microbiology. 